\title{
Notes on the Marine Oligochæta of Plymouth.
}

\author{
By \\ Frank E. Beddard, M.A., \\ Prosector to the Zoological Society of London; Lecturer on Biology at Guy's Hospital.
}

The Oligochæta form a division of the Annelida, of which the most familiar type is the common earthworm (Lumbricus terrestris); the group comprises also a great number of smaller worms, which are for the most part inhabitants of ponds and streams, such as the red River worm (Tubifex rivulorum). The Oligochæta were at one time believed to be entirely terrestrial or inhabitants of fresh water, and to be distinguished thus from the Polychæta, which were supposed to be exclusively marine in their habitat. Although the progress of research has not broken down the structural distinctions between these two divisions of the Annelida chrtopoda, it has been proved that no absolute line of demarcation can be drawn between the Oligochæta and the Polychrta as regards their habitat; on the one hand Polychrta have been found in fresh water, and, on the other hand, certain species of Oligochæta are now known to inhabit the mud and gravel of the seashore.

There are three species common in the Sound at Plymouth, which are apparently identical with certain species described by Claparède* from the shores of Scotland and France.

One of these is a small whitish worm about half an inch in length, which is abundant in gravel between tide marks in Rum Bay. It belongs to the genus Pachydrilus of Claparède, but I have not yet satisfactorily determined to which of the several known species of the genus it should be referred.

The two remaining species are found in mud at Drake's Island and on the shores of the Sound, where they are extremely abundant. They can be distinguished from each other by a slight difference in the transparency of the body wall. One worm is much more transparent than the other, and is therefore of a brighter red colour, this colour being, of course, due to the blood-vessels ; this species appears to be Claparède's Clitellio arenarius. The other worm has a more dusky appearance, caused by the presence of a 
quantity of minute papillæ, filled with a greyish-green pigment, which cover the body except at the anterior and posterior end, and on the clitellum when developed. The opacity of the body walls renders the contained blood-vessels less conspicuous. I identify this worm with Claparède's species Clitellio ater; it is probably also identical with d'Udekem's* 'Tubifex Benedii.

The preliminary list of the Marine Fauna of Plymouth, published in the second number of the 'Journal of the Marine Biological Association,' contains a single Oligochæt-Tubifex lineatus.

Tubifex lineatus is, however, a most mysterious species ; it was originally described by Hoffmeister ; $\dagger$ but there is nothing in Hoffmeister's description which renders its identification possible, unless he is right in stating (by implication) that there are no hair-like setæ in the dorsal fascicles; in this case it cannot be a Tubifex; but the generic name Scenuris, which Hoffmeister applied to it, includes several species which are now assigned to different genera. I should be inclined myself (at least provisionally) to regard "Sœenuris lineatus" as being the same form as Clitellio arenarius, for in that Annelid also, as Claparède stated, there are no hair-like setæ.

Another marine species, found on the coasts of the North Sea, is Tubifex hyalinus, d’Udekem. Vejdovsky $\ddagger$ considers it probable that this is a Limnodrilus, since it only possesses bifid setæ. This is, however, as already stated, no reason against regarding the species as a Clitellio, inasmuch as all the species of Limnodrilus, which have been adequately described, are fresh-water forms; it is more probable, though of course by no means certain, that Tubifex hyalinus is a Clitellio, and perhaps also identical with $\mathrm{Cl}$. arenarius. Claparède was unacquainted with d'Udekem's paper when he described Clitellio arenarius.

Clitellio also agrees with Limnodrilus in the presence of a pair of "hearts" in each of segments 8 and 9. It is in fact only to be distinguished from that genus by (1) the absence of "prostate" glands, (2) the shortness and breadth of the vasa deferentia, and (3) the structure of the spermathecæ, which are composed of two sacs united by a very narrow tube; in the lower sac lie the spermatophores.

The species which Claparède termed Clitellio ater, and only very briefly described, cannot be referred to the genus Clitellio at all. The peculiar papillæ, already referred to, distinguish the species,

* Nouvelle classification des Annelides Sétigeres Abranches, Bull. Acad. Roy. Belg., T. xxii, Pt. ii (1855).

$\dagger$ Die bis jetzt bekannten Arten aus der Familie der Regenwürmer.

‡ System u. Morphol. d. Oligochæten. 
and lead me to infer its identity with d'Udekem's Tubifex Benedii, which appears from the woodcut in Udekem's* paper to possess similar papillæ; this has been already urged by Vaillant. Claparède does not mention the presence of hair-like setæ; these indeed are present in some individuals and absent in others ; when present they exist only in the dorsal fascicles. The only genus of Tubificidæ in which this capricious arrangement of the setæ occurs is Eisen's genus Hemitubifex; $\dagger$ but the only species of that genus is fresh water. Clitellio ater furthermore agrees with Hemitubifex in the dilatation of the termination of the vas deferens connected with the atrium; I am not, however, convinced that this species is an Hemitubifex, though there does not appear to be any other genus to which it can be unhesitatingly assigned.

I have already communicated to the Zoological Society of London a fuller account of the anatomy of these two Tubificidæ.

* Loc. cit., p. 544 .

$\dagger$ Oligochatological Researches, Report of the (U. S.) Commissioners for Fish and Fisheries for 1883. 